\title{
COMMUNITARIAN AND INTERGOVERNMENTAL DIMENSION OF EU VISA LAW
}

\author{
Maciej Cesarz*
}

\begin{abstract}
This article explores the development of EU visa policy with special emphasis put on legal and institutional dimensions. Basing on a formal analysis of primary and secondary law of the European Union and literature on the subject, it claims that intergovernmental roots of common visa policy strongly affect the current structure of EU regulations on visas. The research is focused on the formal development in this area of integration with particular attention paid to the intergovernmental dimension which is still present in the framework of the Schengen visa regime. Visa facilitation agreements as part of EU visa law as well as political determinants of common visa policy are also examined. The article concludes that visa issuing still remains a complex matter, characterized by dispersion of visa $a c$ quis due to separate provisions that still remain in force and which presents a mix of hard and soft law. Since the Member States have retained the right to issue national, long-term visas and the national practice of issuing uniform visas remains varied, European integration in the area of visas is still incomplete.
\end{abstract}

Key words: EU visa policy, Schengen visa, Schengen Area, EU Integrated Border Management

* Assistant Professor, Chair of the European Studies, Faculty of Social Sciences, University of Wrocław, Poland, Maciej.cesarz@uwr.edu.pl 


\section{INTRODUCTION}

The main aim of this paper is to analyze the intergovernmental dimension of European visa policy and law. The key purpose is to outline the determinants of development of common visa regulations and assess an impact of Schengen acquis on the current structure of visa law. These questions are addressed in several steps. Firstly, the political and historical context is provided in order to build a solid analytical framework. Basing on a formal analysis of institutional and legal development of the common visa regime, the paper proceeds to a description of the major sources of European Union visa law. The next section is devoted to a brief summary of changes in decision-making methods and territorial application of Schengen visa regulations. In the last section, based on the findings on a field study carried out for the purposes of this paper, the conclusion is given.

Since the paper is focused on mostly formal aspects of cooperation between EU Member States, the detailed content of current visa law will be not covered. The methodology used for the purpose of this paper is deeply rooted in European studies, with special emphasis put on a legal approach. Hence, the article combines elements of legal and political analysis with reference to the Schengen visa regime. The main sources of information are legal acts and official documents produced on the EU level. The paper is also based on extensive review of recent literature devoted to the European Union visa policy and law.

\section{THE POLITICAL, INSTITUTIONAL AND LEGAL DEVELOPMENT} OF INTEGRATION IN THE AREA OF VISAS

\subsection{Visa cooperation before the Treaty of Amsterdam}

Visa policy was one of the earliest and most successful areas of coordination between European countries, playing a key role in the evolution of the Schengen system. As a result of its application, all Schengen Member States grant uniform short-stay visas in accordance with the same highly structured procedure regulated by the Common Visa Code. This 
achievement was possible mainly due the lifting of internal border controls and the principles adopted, according to which a third-country national (TCN) may, after entering the territory of one of the Schengen zone countries, move freely within the territories of the other countries of the group. Obviously, the diversification of national visa regimes could have had a negative impact on the level of security of the entire area covered by the free movement of persons, in particular in the context of the threat of an uncontrolled inflow of illegal immigrants, forcing the introduction of common rules with reference to mobility. In connection with the above, issuing visas currently remains the basic procedure for granting permission to enter the Schengen member states as well as candidate countries.

While migration and border controls take place at the border and within the territory of the EU, several legislative instruments have introduced measures that are implemented before a TCN enters the territory of a member state, including visa policies, carrier sanctions, advance passenger information and immigration liaison officers ${ }^{1}$. Both the Council of the European Union and the European Commission have consistently perceived the common visa policy in terms of a basic measure preventing irregular migration to the EU and limiting potential threats to its security ${ }^{2}$. In fact, the activity of the Communities and the Union in this field was largely inspired by the desire to reduce illegal immigration, although the proper beginnings of visa harmonization dates back to the crisis of the early 90s, when Northern European countries experienced a sudden increase in the number of asylum applications resulting from the collapse of the communist bloc. The visa restrictions adopted at that time were aimed at limiting the inflow of potential asylum seekers from post-socialist countries to the EU countries, in particular Germany and France.

Two decades of mass asylum-seeking convinced European liberal states, that "once the asylum seeker is „in”, it is most difficult to get him

1 Lena Karamanidou, Bernd Kasparek, Global Migration: Consequences and Responses, Respond Working Papers, Paper 2018/14, July 2018, 34.

2 European Commission (2009) Evaluation of the implementation of the European Community's visa facilitation agreements with third countries, Commission Staff Working Document SEC (2009)1041final, Bruxelles: European Commission, 1. 
out"3. Therefore national governments have expressed special interest in measures applied ex-ante, that would prevent the entry of persons who could potentially apply for refugee status. The visa policy was an important element of the catalog of preventive means adopted by EU Member States, implemented together with the concept of the first safe third country, sanctions imposed on carriers and an improved border control system ${ }^{4}$. The strategy proved effective and resulted in significant reduction in the influx of potential refugees in Europe in the 90s, particularly in Germany, which was also the first Western European country that decided to systematically implement visa restrictions ${ }^{5}$. As it turned out quickly, effectiveness of the new established visa regime was largely determined by the degree of cooperation with neighboring countries: when Federal Republic tightened its visa admission rules, migration flows were quickly redirected to the GDR, from where potential asylum seekers could enter West Germany via Berlin. The situation changed only in 1986, when the GDR authorities finally agreed to adopt an equally restrictive visa regime ${ }^{6}$.

Germany's experience on the grounds of issuing visas and the impact of cooperation with other countries pursued in order to improve border controls shaped to a large extent the course of negotiations leading to the conclusion of the Schengen Agreement in 1985. It was the German delegation who requested to attach an annex to the treaty combining the abolishment of internal border controls with compensatory measures, including common visa restrictions ${ }^{7}$. The five-year period between the conclusion of the Schengen Agreement (1985) and the adoption of the Convention im-

3 Christian Joppke, „Asylum and State Sovereignty: A Comparison of the United States, Germany, and Britain", In: Christian Joppke, ed., Challenge to the Nation-State: Immigration in Western Europe and the United States, Oxford, 1998, 141.

4 Sandra Lavenex, „Migration and the EU's new eastern border: Between realism and liberalism", Journal of European Public Policy, 8(1), 24.

5 UNHCR. (2011) Asylum Levels and Trends in Industrialized Countries 2010, https://www.unhcr.org/4d8c5b109.pdf.

6 Claudia Finotelli, Giuseppe Sciortino, „Through the Gates of the Fortress: European Visa Policies and the Limits of Immigration Control", Perspectives on European Politics and Society, 2013: 503.

Claudia Finotelli, Giuseppe Sciortino, Through the Gates of the Fortress... op.cit., 503. 
plementing the Schengen Agreement $(1990)^{8}$ to which all Member States acceded by 1996 (except for the United Kingdom and Ireland) was of particular relevance for the development of the modern border management in the European Union. The issue of immigration, including harmonization of visa policies and other border control measures has become the axis of cooperation between Member States. The system implemented in the framework of the intergovernmental formula provided instruments allowing effects on the national visa policies of countries who expressed the will to join the Schengen area: for example, due to new measures Germany and France could effectively exert pressure on the Italian government to introduce visas for Turkish citizens and the Maghreb countries, which were the most important transit countries for illegal immigrants heading to the rich countries of Northern Europe. While earlier Rome had rejected this concept as contrary to Italian Mediterranean policy, the potential benefits arising from accession to the Schengen Agreement prevailed. Eventually Italian authorities decided to introduce visa requirements at the beginning of the 90s for the citizens of third countries mentioned, thus fulfilling the condition for joining the Schengen Area?

Diverted geopolitical interests and conditions have proved problematic for the further development of the common visa regime, resulting in different understanding of its priorities by the signatories of the Schengen agreements. While harmonization was undoubtedly the main goal for all governments, its implementation based on the intergovernmental (not communitarian) method generated numerous political and legal disputes between states as well as between the European Council and the Commis$\operatorname{sion}^{10}$. The Schengen Executive Committee, set up under the Convention, adopted a number of decisions establishing detailed rules on visa issuing and eventually the Common Consular Instructions (CCI), which collated such decisions and the relevant Convention articles in one document ad-

8 Convention implementing the Schengen Agreement of 14 June 1985 between the Governments of the States of the Benelux Economic Union, the Federal Republic of Germany and the French Republic on the gradual abolition of checks at their common borders, OJ L 239, 22.9.2000.

9 Claudia.Finotelli, Giuseppe Sciortino, Through the Gates of the Fortress... op.cit., 504.

10 Annalisa Meloni, Visa Policy within the European Union Structure, Berlin-Heidelberg, 2006, 66. 
dressed to national consular authorities for the purpose of determining visa applications ${ }^{11}$. Since CCI were issued to all participating Schengen states' consular authorities for the purpose of determining visa applications, they may be considered a precursor for the Common Visa Code ${ }^{12}$. However they were confidential and remained confidential until they became part of EU law ${ }^{13}$, which made the visa rules even less clear and transparent. As a sole legal act listing procedures and conditions for issuing visas and rules on a uniform visa and thus regulating the implementation of the Schengen visa policy, CCI constituted a "soft law" (meaning non-directly binding act such as Council communications) ${ }^{14}$.

In parallel to these developments, the Treaty of Maastricht (agreed in 1992) introduced Article 100c EC conferring competence to the Community to adopt the list of countries whose nationals required a visa to cross the external borders of the Member States and a uniform format for visas ${ }^{15}$. In 1995, based on the Maastricht Treaty provisions, the Council of the newly established European Union adopted Regulation No. 2317/1995, introducing a common list of 101 third countries whose citizens were required to obtain a visa to enter the territories of the EU Member States. However, it was decided to exclude the third countries that were previously covered by an agreement on visa-free travel with at least one EU state; it was also left up to Member States to decide on whether to impose a visa requirement for countries not included on the "black-list"16. Importantly,

11 Annalisa Meloni, Visa Code Regulation (EC) No 810/2009, in K. Hailbronner, D. Thym, Ed., EU Immigration and Asylum Law - A Commentary, Baden-Baden: Nomos, 2016, 122.

12 Annalisa Meloni, Visa Code Regulation (EC)..., op.cit., 122.

13 ICMPD, How harmonised can visa policy be? The new EC proposals on Schengen visa rules, Policy Brief, November 2014, 2.

${ }_{14}$ Federica Infantino, Schengen Visa Implementation and Transnational Policymaking. Bordering Europe, PalgraveMacmillan, 2019, 44.

15 Annalisa Meloni, Visa Code Regulation (EC)..., op.cit., p.122.Regulation (EC) No 2317/95 (OJ 1995 L 234/1) on the visa list was adopted in 1995 and soon replaced by Regulation (EC) No 574/1999 (OJ 1999 L 72/2) following ECJ, Parliament v Council, C-392/95, EU:C:1997:289. Regulation (EC) No 1683/95 (OJ 1995 L 164/1) on the visa format was also adopted in 1995.

16 Elena Jileva, "Visa and free movement of labour: The uneven imposition of the EU acquis on the accession states", Journal of Ethnic and Migration Studies, 2002, 28(4), 683-700. 
the agreed Regulation also enabled further existence of the circular migration, which was typical for European countries of the 90s, indicating that from the very beginning the implementation of the objectives of the common visa policy was characterized by susceptibility to geopolitical impuls$\mathrm{es}^{17}$. Although the Article 100c of the EC Treaty (inserted by provisions of the Maastricht Treaty) conferred the power to adopt visa list binding for all Member States on EU institutions, the new established regime finally resulted in an extremely restrictive visa law, as national visa restrictions had been cumulated ${ }^{18}$.

The uniform format for Schengen visas was laid down by the Council in 1995, however procedures and conditions for issuing visa documents remained the subject of intergovernmental cooperation under the newly established Third Pillar (Justice and Home Affairs) of the European Union, with no progress achieved on this front ${ }^{19}$. Additionally, under the Third Pillar Joint Action 96/197/ JHA on airport transit visas was adopted, listing the nationalities requiring airport transit visas, which gave rise to another inter-institutional conflict regarding the division of competence for visa policy between the Community and the Third Pillar of the $\mathrm{EU}^{20}$.

\subsection{Amendments adopted on the basis of the Treaty of Amsterdam}

As has been mentioned in the European context, harmonization of visa policies has been on the agenda since the early 1990s, however it has been a difficult process, as individual Member States faced varied national realities and pursue different interests ${ }^{21}$. EU inter-institutional conflicts and divisions among Member States have been largely reduced after the entry into force of the Treaty of Amsterdam, under which existing visa acquis (previously developed through intergovernmental cooperation based on Schengen provisions) has been incorporated in the institutional and

17 See Ewa Morawska, "Gappy immigration control, resourceful migrants and pendel communities", In: Controlling a new migration world, ed. V. Guiraudon and C. Joppke 2001, London, 173-199.

18 Federica Infantino, Schengen Visa Implementation..., op.cit., p.43.

19 Annalisa Meloni, Visa Code Regulation (EC)..., op.cit., p.122.

20 Ibidem.

21 ICMPD, How harmonised can visa..., op.cit., p.1-2. 
legal framework of the Union. Under the Amsterdam Treaty the founding of the EU Area of Freedom, Security and Justice (AFSJ) was also initiated, where the free movement of persons was guaranteed in conjunction with appropriate measures with regard to external border control, asylum, immigration and the prevention and combating of crime ${ }^{22}$.

The new area of cooperation established by the Treaty of Amsterdam included the provisions of Title IV of the EC Treaty, referring to visas, asylum, immigration and other policies related to the free movement of persons. Controlling external borders of the EU, regulations on the movement of third-country nationals on the territory of the Union and judicial cooperation in civil matters have also become the subject of the Community regime. However other provisions contained in the TEU on police and judicial cooperation in criminal matters still remained intergovernmental. Furthermore, transfer of policies regarding admission of TCNs has raised opposition from Denmark, Ireland and the United Kingdom, which explains why the Amsterdam Treaty was accompanied by protocols containing the separate positions of the states concerned, excluding them from the application of measures adopted by the Union under Title IV of the TEC.

With the incorporation of the Schengen acquis in the system of EU law (based on Protocol 2 of the Treaty of Amsterdam) visa, immigration and asylum policy eventually came under EU competence. The relationship between the Schengen rules and Community law was governed by the Schengen Implementing Convention and Protocol 2: which stipulated that the Schengen acquis must comply with Community (EU) law, as later confirmed by the Court of Justice of the EU (CJEU) in its case-law ${ }^{23}$. The amended Art. 62 TEC generally granted the Community the right to decide on the conditions and procedures for issuing visas. More precisely Article 62 para. $2 \mathrm{~b}$ ) required the Council to adopt rules regarding visas for stays of no more than 3 months, including: a list of third countries whose nationals are subject to the visa requirement to cross external borders and third countries whose nationals are exempted from this obligation, proce-

${ }^{22}$ Art. 3, Consolidated version of the Treaty on European Union, OJ C 326, 26.10.2012.

23 Case C-503/03 Commission v Spain. 
dures and conditions issuing visas by Member States as well as the uniform format for visas and the rules for the issuance of a uniform visa. In fact, the new wording of Article 62 TEU largely reflected the content of Articles 1-2 of the Schengen Convention and other existing (or proposed solutions) in the area of visas. Declaration No. 16 attached to the Treaty was also of key importance, according to which during application of Article 62 para. 2 lit. b) TEU account must be taken of the foreign policy arrangements of the Union and the Member States. This declaration should be interpreted in the context of the principle agreed, according to which even uniform visas were to be issued by the national authorities of the Member States.

The decision-making process in visa matters was governed by Article 67 (1), which provided that for a transitional period of five years from the entry into force of the Treaty of Amsterdam, the Council would take decisions unanimously on a proposal from the Commission or on the initiative of a Member State and after consulting the European Parliament. However, by way of derogation, measures on visa lists and visa format from the entry into force of the Amsterdam Treaty were to be adopted by the Council by a qualified majority vote (QMV) on a proposal from the Commission and after consultation with the European Parliament. In accordance with Art. 67 para. 2 from May 1, 2004 the Commission obtained a monopoly on legislative initiative in all visa matters, which were henceforth to be decided by the Council by QMV together with the European Parliament under the co-decision procedure.

Since the adoption of the Amsterdam Treaty, the EU legal order includes a comprehensive set of provisions governing the issue of short-stay visas and the movement of TCNs. The issue of further development of legislation in this area was raised at the Tampere Summit, pointing the need to develop a common, active policy in the area of visas and forged documents, closer cooperation between consulates of EU Member States in third countries and the establishment of joint offices responsible for issuing Schengen visas ${ }^{24}$. Nevertheless under the influence of the events of September 11, 2001, the priorities of the EU changed and the process of securitization of policies related to the movement of persons was

24 Steve Peers, EU Justice and Home Affairs Law: Volume I: EU Immigration and Asylum Law, Oxford, 2016, 170. 
intensified. This was manifested by the establishment of the Visa Information System (VIS), containing information on all persons applying for a Schengen visa, amendment of provisions regulating uniform visa format for increasing the security standards of this document and number of changes regarding visas issued at the border ${ }^{25}$. At present Regulation (EC) $767 / 2008$, which established the use of the Visa Information System (VIS) for the storage and exchange of data on short-term visas issued by member states determines primarily the data to be stored in VIS when an application is submitted, and a visa is issued, refused, annulled, revoked or extended ${ }^{26}$.

While national visa authorities are responsible for entering and (when necessary) amending the stored data, the database can be accessed by border control and law enforcement authorities as well as by other Member States ${ }^{27}$. In addition to establishment of the VIS, freedom of movement was extended to include TCNs holding long-stay visas. Finally, a consent was achieved to conclude an agreement with Switzerland, allowing the country to apply the Schengen acquis and the first agreement on visa facilitation concluded with a non-EU country (Russia) was also concluded ${ }^{28}$. Due to the progress in communitarizing of the compensatory measures the Common Consular Instructions were also published in the Official Journal after the Schengen acquis was incorporated into the EU legal framework ${ }^{29}$.

\subsection{The role of Lisbon reform}

Since the entry into force of the Lisbon Treaty (December 1, 2009), uniform visas has remained the basic mode of granting permission to enter the Schengen area and the EU candidate states (also obliged to im-

25 (Regulation (EC) No 767/2008 of the European Parliament and of the Council of 9 July 2008 Concerning the Visa Information System (VIS) and the Exchange of Data Between Member States on Short-Stay Visas (VIS Regulation) 2008).

26 Art. 5, 9-14 Regulation VIS, Lena Karamanidou, Bernd Kasparek, Global Migration..., op.cit., 35 .

27 Art. 6, 18, 19 Regulation VIS. Lena Karamanidou, Bernd Kasparek, Global Migration...,op.cit., 35 .

28 Steve Peers, EU Justice..., op.cit., 170.

29 Federica Infantino, Schengen Visa Implementation..., op.cit., 44. 
plement the provisions of the Schengen acquis). Article 62 (2) TEU and Article 77 of the Treaty of Lisbon establish the Union's legislative capacity for introducing legislation on short-term visas and for lists of countries whose nationals must possess a visa when entering an EU member state ${ }^{30}$. After the Lisbon reform, art. 77 section 2 (a) of the Treaty on the Functioning of the European Union (TFEU) constitutes the legal basis for EU visa policy, covering also other matters and principles of integrated border management. Pursuant to Article 77 (1) TFEU, the EU shall develop a policy aimed at ensuring the absence of any controls on persons, whatever their nationality, when crossing internal borders; ensuring control of persons and effective supervision when crossing external borders and gradual introduction of an integrated management system for external borders. Paragraph 2 emphasizes the close relationship between visas and border control: to achieve the objectives listed in paragraph 1 of Art. 77 TFEU, the European Parliament and the Council, acting in accordance with the ordinary legislative procedure, adopt measures concerning common policy on visas and other short-stay documents, conditions for the free movement of TCNs within a short period within the Union and the absence of any controls on persons, whatever their nationality, when crossing internal borders.

Importantly, unlike the previous version of the treaty, the text introduced by the Lisbon reform contains a direct reference to the "common visa policy", emphasizing the coherence of the treaty provisions in this $\operatorname{area}^{31}$. In addition, the competences of the EU institutions were expanded by the change in the wording: in accordance with art. 62 para. 2 lit. b) as amended by the Amsterdam Treaty, the Council adopted rules on "visas for stays not exceeding three months"; while the new version abandoned the time restriction, associating the EU competence with the right to adopt measures in the field of "visas and other short-stay documents". Thus, the common visa policy was expanded to include rules for issuing "other documents" allowing a short stay in the territories of the Member States.

30 Lena Karamanidou, Bernd Kasparek, Global Migration...,op.cit.,.34.

31 Moreno-Lax Viloleta, Accessing Asylum in Europe. Extraterritorial Border Controls and Refugee Rights under EU Law, Oxford, 2017, 83. 
As part of the profound reform of the system carried out under the Lisbon Treaty (which assumed the abolition of the previous three-pillar structure), the unification of the decision-making mechanism and the catalog of sources of EU law, all issues of the AFSJ were regulated in one Title V TFEU. Thus, the competences in visa matters previously scattered between areas governed by the Community and intergovernmental regime were eventually merged. The Lisbon Treaty also changed the decision-making procedure as regards visa lists - legislation in this area must now be adopted by means of the ordinary legislative procedure, which entails QMV in the Council with the joint decision-making power of the European Parliament $^{32}$. This, as Moreno-Lax has put, gives the new EU visa policy a truly supranational character ${ }^{33}$. As part of treaty development, the jurisdiction of the CJEU has also been extended to visa issues, although the Court presents relatively low activity in this area.

\section{THE VISA CODE, VISA LISTS AND FACILITATION AGREEMENTS}

The visa application criteria and procedures were then systematized in 2009 by the adoption of the Community Code on Visas (widely referred to as Visa Code), which became applicable on 5 April $2010^{34}$. The code is a clear manifestation of the securitization of EU immigration policy, in which Schengen visas played an increasingly growing role. With Regulation 810/2009, the EU pooled all legal acts governing the conditions and procedures for issuing short-stay visas into one piece of legislation and repealed obsolete parts of the Schengen acquis ${ }^{35}$. The Regulation also replaced provisions on visa issuing which were previously scattered in various instruments, some of which of unclear legal nature, such as articles of the Schengen Implementing Convention, the Common Consular Instructions (CCI), Schen-

32 Steve Peers, EU Justice and Home Affairs, op.cit., 226.

33 Violeta Moreno-Lax, Accessing Asylum in Europe..., op.cit.,.83.

34 (Regulation (EC) No 810/2009 of the European Parliament and of the Council of 13 July 2009 Establishing a Community Code on Visas (Visa Code) 2009.

35 ICMPD, How harmonised can visa..., op.cit., 2. 
gen Executive Committee Decisions, the Joint Action on Airport Transit Visas and various EC Regulations ${ }^{36}$.

Despite the fact that nowadays TCNs must fulfill several conditions to cross the the borders of Schengen area, different criteria for issuing Schengen visa exist - they are regulated for the first time by the Visa Code, which is self-executing and first legally binding act that tackles the uses of discretion for examining applications ${ }^{37}$. The Regulation is exhaustive in covering all aspects of the Schengen visa implementation - it sets common rules for the issuance of short-term visas and establishes lists of countries whose nationals must obtain airport transit visas before entering EU territory $^{38}$. Furthermore, the Code designates the Member States responsible for receiving visa applications, examining and application, stipulates rules for lodging applications, the biometric identifiers and documents required and Schengen visa fees ${ }^{39}$. Regulation 810/2009 sets out also the rules for examining, issuing, modifying and annulling visa application ${ }^{40}$, which in connection with uniform format for Schengen visas ${ }^{41}$, VIS and a (legally non-binding) Handbook for the processing of Visa applications ${ }^{42}$ constitutes the new toolbox of the common visa policy.

However the intergovernmental roots of EU visa policy have left their trace, as the Code serves also as a source of national discretion. In cases of

36 Annalisa Meloni, Visa Code Regulation (EC)..., op.cit.,123.

37 The Schengen Borders Code communitarizes the conditions that nationals of third countries have to fulfill in order to enter the Schengen territory provided in the Schengen Implementation Agreement (possession of a valid travel documenta and a valid visa where applicable; production of documents justifying the purpose and conditions of their visit and proof of means of support; TCNs are not reported in the Schengen Information System and are not considered as a threat to the public policy, national security, or the international relations of any of the Contracting Parties. Federica Infantino, Schengen Visa Implementation..., op.cit., 45.

38 Art. 1 para. 3 Visa Code. Federica Infantino, Schengen Visa Implementation..., op.cit., 45.

39 Art. 4, 6, 9-15, 116-117 Visa Code.

40 Art. 18-36 Visa Code.

41 (Council Regulation (EC) No 1683/95 of 29 May 1995 Laying down a Uniform Format for Visas 1995.

42 Handbook for the processing of visa applications and the modification of issued visas. Commission Decision, 19 March 2010, C (2010) 1620 final. 
'mass influx of illegal immigrants', Member States can require nationals of countries not on the list to obtain airport transit visas; they may also issue (primarily for humanitarian reasons, national interests or international obligations) visas with limited territorial validity, allowing the holder to travel only to one or more selected Schengen states ${ }^{43}$. The Visa Code should be also considered within the context of the EU external border control system and even wider, fast developing EU 'area of freedom, security and justice ${ }^{34}$, which is characterized by integration referring to variable geometry. The Regulation does not apply to the United Kingdom and Ireland by virtue of the 5th Protocol on the Schengen acquis integrated into the framework of the European Union attached to the Treaties, but applies to Denmark under international law in accordance with the Protocol on the position of Denmark (attached to the Treaties) and to Iceland, Norway, Switzerland and Liechtenstein by virtue of agreements between the EU and these countries on their association with the implementation, application and development of the Schengen acquis $^{45}$.

Since its adoption, common policy as regards short-term visas has faced a significant challenge: the delicate equilibrium between the need to promote economic growth via mobility and tourism, on the one hand, and the need to ensure the security of the Schengen area, on the other ${ }^{46}$. Assessments of the implementation of the Visa Code and the VIS have shown that the restricting requirements for obtaining a Schengen visa have had a negative impact on tourism and as a result, on EU economic growth ${ }^{47}$. As a result, on 14 March 2018, the Commission adopted a proposal to revise the Visa Code, with the main objective to strengthen the common visa policy while addressing migration and security concerns. This will involve increasing the role of visas in the EU's cooperation with third-countries by linking the entry permissions with readmission and broader EU external policy. The proposal also intends to

43 Art 25 para 1 Visa Code. Lena Karamanidou, Bernd Kasparek, Global Migration...,op.cit., 35 .

44 Annalisa Meloni, Visa Code Regulation (EC)..., op.cit., 123.

45 Ibidem, p. 125.

46 Revision of the Visa Code (Regulation 810/2009) and Visa Information System (Regulation 767/2008) http://www.europarl.europa.eu/RegData/etudes/ BRIE/2018/615646/EPRS_BRI\%282018\%29615646_EN.pdf [last access: 28.01.2019]. 47 Ibidem. 
facilitate processing of visas for legitimate travelers who contribute to the EU's economy and its cultural and social development ${ }^{48}$.

Visa Code arrangements for the issuance of visas are regulated by other legislative acts, including Regulation 539/2001 establishing common lists of countries whose nationals must hold visas when entering European Union territory (the 'black list') and countries that are exempt from such requirement (the 'white list') ${ }^{49}$. This follows the amendments introduced by the Amsterdam Treaty which conferred on the Community the powers to decide on the list of third countries whose nationals must be in possession of visas when crossing external borders and those whose nationals are exempt from that requirement ${ }^{50}$. The inclusion of countries in the black list is done on a case by case basis, based on criteria such as 'illegal immigration, public policy and security, and to the European Union's external relations with third countries, consideration also being given to the implications of regional coherence and reciprocity ${ }^{31}$. The decision-making rules with reference to black-list are based on QMV in the Council with consultation of the European Parliament. The exemption or not of a third country from visa requirements is dependent on negotiations between the $\mathrm{EU}$ and the state concerned and subject to third countries adopting measures on a range of issues such migration control capacity, preventing irregular migration, combatting organized crime and upholding the rule of law and human rights ${ }^{52}$.

48 The main points of the revised proposal include joining up visa and return policies by increasing the role of visa policy in the EU's cooperation with third-countries, specifically on migration management; increasing the visa fee; introducing a harmonised approach (mandatory rules) to issuing multiple-entry visas with long validity; simplified visa procedures and facilitating short-term tourism, including a possibility for Member States to issue single-entry visas at the external borders in exceptional situations. Revision of the Common Visa Code, http://www.europarl.europa.eu/legislative-train/theme-towards-anew-policy-on-migration/file-revision-of-the-common-visa-code [last access: 28.01.2019].

49 Lena Karamanidou, Bernd Kasparek, Global Migration..., op.cit., 34.

50 Art. 62 (2) (b)(i) TEC.

51 Council Regulation (EC) No 539/2001 of 15 March 2001 listing the third countries whose nationals must be in possession of visas when crossing the external borders and those whose nationals are exempt from that requirement OJ L 81, 21.3.2001Rec. 5. Lena Karamanidou, Bernd Kasparek, Global Migration..., op.cit., 34.

52 Lena Karamanidou, Bernd Kasparek, Global Migration..., op.cit.,34. 
One must note, that the issuance of Schengen visas after 2000 significantly determined relations with third countries, becoming also a driving force of EU external policy. Visa policies always have a strong foreign policy dimension, reflecting and impacting on interstate relations and the European Union is no exception ${ }^{53}$. Unions foreign policy, defined as a bunch of individual (not always compatible) interests of the Member States, the demand for internal security and the strategy for protecting the external borders of the European Union were the most relevant factors shaping the structure of the common visa regime and the content of the black and white visa lists. In the age of globalization, it was recognized that the Union should, through an integrated approach to the issue of access control to the territory, facilitate the mobility of persons, while ensuring an adequate level of security. This interdependence of pre-entry controls with other dimensions of the Union's activity is particularly evident in case of EU visa relations with Eastern Europe and the Balkans. Facilitation and even abolition of visa obligations in this case were initially planned to increase the internal security of the Union by exporting its restrictive normative standards in the field of border protection and control. Most often, they were also an additional argument prompting third countries to conclude readmission agreements with the Union in exchange for establishing a visa road map as was among others, the case of Ukraine and Turkey ${ }^{54}$. Thus, visa facilitation agreements are part of common EU policy and are entered with the aim of facilitating the issuance of visas between EU member states and third countries ${ }^{55}$.

From the very beginning the restrictive dimension of the common visa policy was limited by geopolitical interests related to the enlargement of the European Union to the East. Once again, Germany played a dominant role in this process, lobbying in 1991 for the lifting of the visa requirement for citizens of Poland, the Czech Republic and Hungary, perceiving these countries as transit and at the same time crucial territories to

53 ICMPD, How harmonised can visa..., op.cit., 1.

54 Maciej Cesarz, Dialog wizowy UE z Turcją w świetle porozumienia o readmisji z I 6 grudnia 2013 roku, In: Integracja europejska. Główne obszary badawcze, ed. K.A. Wojtaszczyk, J. Tymanowski, P. Stawarz, Warszawa, 2015.

55 Lena Karamanidou, Bernd Kasparek, Global Migration..., op.cit.,35. 
stop irregular migration from other third countries. In addition, the recognition of countries mentioned as "safe" allowed for relaxing the pressure exerted on the German asylum system. Since then, visa policy has become a permanent component of the enlargement process and the acceptance of principles referring to movement of persons and external border controls, including common visa rules, has been recognized as a condition of accession $^{56}$.

In this context the implementation of a common visa policy by the candidate states is an exemplification of Europeanization operating on a "top-down" basis, which should be perceived as the Unions geopolitical attempt to stabilize its external border ${ }^{57}$. The development of the common visa regime influenced heavily the Eastern Partnership program, which clearly separated the EU's relations with Eastern European states from relations with other third countries covered by the European Neighborhood Policy (ENP) launched in 200458. The declared goal of the initiative was to prevent the emergence of new dividing lines between the enlarged EU and its neighbors and to facilitate passenger traffic, while maintaining or improving a high level of security ${ }^{59}$. The Eastern Partnership instruments offer potential benefits to partner countries that show particular determination in the process of reforming their institutions and legislation in terms of EU standards. As a manifestation of Europeanization "ad extra", they are based on association agreements introducing a deeper level of political and economic cooperation with the EU, offering visa facilitation programs or even visa-free travel ${ }^{60}$.

56 Ruben Zaiotti, Cultures of Border Control: Schengen and the Evolution of European Frontiers, Chicago, 2011, 153.

57 James W. Scott, "The EU and Wider Europe: Toward an Alternative Geopolitics of Regional Cooperation?”, In: Geopolitics, 2005, vol. 10, 429.

58 Szymon Ananicz, Partnerstwo Wschodnie, Infos, Biuro Analiz Sejmowych, nr 17, (64) 24.09.2009, 2, In: www.orka.gov.pl [last access: 28.01.2019].

59 European Commission (2004) European neighbourhood policy. Strategy paper, Bruxelles: European

Commission, (COM(2004)373 final), 3, 17.

${ }^{60}$ Janusz Ruszkowski, Europeizacja ad extra w zarządzaniu zewnętrznym (external governance) Unii Europejskiej, In: Rocznik Integracji Europejskiej, nr 4, 2010, 9-27, [last access: 28.01.2019] http://wnpid.amu.edu.pl/images/stories/rie/4-2010/007-028.pdf . 


\section{SUMMARY OF CHANGES IN DECISION-MAKING METHOD AND VARIED TERRITORIAL APPLICATION OF EU VISA LAW}

Summarizing the integration in the visa field, the process of communitarization of competences understood as conferral of competences on the $\mathrm{EC} / \mathrm{EU}$ institutions is significant. Insofar as the development of visa policy under the Schengen Agreements was subject to an intergovernmental regime, since the entry into force of the Treaty of Amsterdam under Title IV of the TEC only a distinction has already been made between two categories of visa competence: the first one concerned visa lists and visa format: in this area decisions were taken by the Council by a QMV, while the Commission had a monopoly of legislative initiative. The adopted acts constituted part of Community law and as such were also applied to Denmark. The second concerned all other measures in the field of visas and freedom of movement of persons. The decisions in these matters were taken by the Council unanimously whereas the legislative initiative was mixed. Consequently the measures adopted were not applied to Denmark ${ }^{61}$.

After changes in the decision-making process carried out during the Amsterdam period in 2004-2005, there were two methods of legislating in the field mentioned: the first concerned uniform visas, conditions for issuing visa documents and freedom of travel, where decisions were taken on the basis of a qualified majority and co-decision procedure (measures were not applicable to Denmark). The second method was used when adopting acts regarding the format of visas, visa lists and administrative cooperation - decisions were taken by the Council on the QMV basis after consultation with the European Parliament (solutions regarding the format of visa and visa lists were applied to Denmark, excluding the principles of administrative cooperation).

Due to major changes brought by the Treaty of Lisbon distinctions in the decision-making process remained only in the sphere of administrative cooperation, as defined in Article 74 TFEU, where the Council continues to act by QMV, subject to the requirement of only consulting the Parliament. However, other measures on visas are adopted on the basis of Article 77 TFEU. There are still separate rules for Denmark,

${ }^{61}$ Steve Peers, EU Justice and Home Affairs..., op.cit., 173. 
which applies EU rules on visa lists and visa format (as part of its EU law) but which is excluded from the application of general standards on visas and freedom of movement (which is a consequence of derogation clauses obtained by that Member State in the area of integration related to Justice and Home Affairs).

The diverse level of participation in the common visa policy of several EU countries, which for various reasons do not fully apply its provisions is another trace of intergovernmental dimension of this area of European integration. Partial involvement of Denmark in the implementation of EU visa law is subject to Protocol 22 annexed to the Treaties, pursuant to which the country remains outside the common visa, immigration and asylum policy, with the freedom to participate in any of the above instruments by mere notification to the Council. In practice, the difference between the situation of Denmark and other signatory countries of the Schengen Treaty equals to adoption of measures based on the Schengen acquis with a several months delay ${ }^{62}$. However, it follows that the above-mentioned instruments are not considered EU law insofar as they apply to Denmark and they bind the state concerned under international law. As a result, the country is only bound by selected visa measures, including the establishment of a list of third countries whose nationals are required to possess a visa when crossing the external borders of the Member States ("black visa list") and a unified visa format.

Additionally, current Schengen Area (apart from 22 EU Member States) also includes 4 EFTA countries: Iceland, Norway, Liechtenstein and Switzerland. These states became participants in the free movement zone after incorporation of the Schengen acquis into EU law by the Amsterdam Treaty, thus they are very closely connected with the Union. Unlike Ireland and the United Kingdom, they recognize the abolition of internal border controls also for TCNs who have legally entered the Schengen area and constitute a single legal space with reference to the free movement of persons, which is subject to EU visa regulations. In turn, Bulgaria, Croatia, Cyprus and Romania are in the process of accession to Schengen, but

62 Anna Szachoń-Pszenny, Wymiar prawny i terytorialny strefy Schengen, In: System Schengen a imigracja z perspektywy Polski i Niemiec, ed. M. Trojanowska-Strzęboszewska, Warszawa, 2014, 35. 
they are obliged to implement a visa policy based on the Schengen acquis. By contrast, Ireland and the United Kingdom are not bound by the Schengen rules, but at the request of their national governments the provisions of the acquis are partially applied ${ }^{63}$. These countries do not belong to the Schengen area because of the opt-out obtained, which allows them to implement the visa policy on their own separate rules.

\section{CONCLUSION}

While specific legislation on visa policy (Visa Code) was only adopted in 2009, there had been a gradual harmonization of visa policies for about two decades preceding that date $e^{64}$. One can put forward the thesis that political conditions have from the beginning been an important counterargument for the establishment a decidedly restrictive visa policy on the level of the European Union. Instead of achieving the generally defined goal expressed by the principle of "no illegal immigrants at all costs", EU implemented rather a long-term and moderately restrictive strategy, allowing for a limited inflow of irregular immigrants from selected (mostly European) countries, with the intention of maintaining good relations with the neighbors and guaranteeing efficient implementation of readmission agreements $^{65}$.

Summarizing the development of the common visa policy, its non-Community, intergovernmental dimension should be emphasized: the starting point was the Schengen Implementing Convention adopted outside the Community framework in 1990, establishing a uniform format for a visa valid in the territory of all countries that have acceded to free movement zone. Only the Treaty of Amsterdam enabled the common visa policy (so far developed under the intergovernmental regime) to be eventually implemented due to the incorporation the Schengen acquis in the

63 Anna Szachoń-Pszenny, Acquis Schengen a granice wewnętrzne i zewnętrzne w Unii Europejskiej, Poznań, 2011, 122.

64 ICMPD, How harmonised can visa..., op.cit., 1.

65 Claudia Finotelli, Giuseppe Sciortino, Through the Gates of the Fortress... op.cit., 507. 
institutional and legal framework of the Union with the possible opt-out in case of Great Britain, Ireland and Denmark. The rules for issuing uniform visas were later developed within EU legislation, which consequently led to the harmonization of Member States' activities in this field and the adoption of a binding list of third countries whose citizens require a visa before entering the EU or are exempt from this obligation.

Besides introduction of a uniform visa format, the technical aspect of visa cooperation within the Union has been covered by the establishment of the Visa Information System (VIS), the adoption of secondary legislation imposing sanctions on carriers. Although the TFEU mandated the European Parliament and the Council to adopt measures concerning the common policy on visas and other short-stay residence permits, such regulations cover only the short-term visas (up to 90 days) while the issuing of long-term visas remains the exclusive competence of the Member States ${ }^{66}$. Thus, Schengen visa is currently the basic document confirming that a given person meets the conditions for entry into the territory of the Schengen States, although the countries have retained the right to issue national visas (long-term visas) which are not part of the common visa policy and are not subject of EU law.

One must note, that as long as Schengen visas are governed by EU legislation, the processing of the visa application and the granting of a visa are not the responsibility of the EU institutions, but the Member States whose territory is the destination of the visit. Additionally, although there are provisions on the issuing of multiple entry visas (MEV), their mandatory nature is undermined by the discretionary assessment of eligibility conditions for a MEV, which include the notions of 'integrity' and 'reliability ${ }^{36}$. Furthermore, Member States are still equipped with the power to issue Schengen visas with limited territorial validity (LTV), which weakens the common character of Schengen visas. Common policy still allows for national discretion with reference to Schengen visa issuance: it has been observed that despite the progressing harmonization process, the national

66 ICMPD, How harmonised can visa..., op.cit., 2.

${ }_{67}$ ICMPD, How harmonised can visa..., op.cit., p.3. 
practice of issuing uniform visas still remains heterogeneous ${ }^{68}$. While Visa Code has provided for further harmonization of the Member States' visa issuing practices, it appears that there are still variations resulting from the soft law nature or vagueness of some of the rules ${ }^{69}$. A comparison of visa activities of various Member States consular offices revealed significant differences in the implementation of EU visa policy and the unflagging role of national determinants, including bilateral relations and historical connections in shaping the practice of granting Schengen visas ${ }^{70}$.

Apart from the varied territorial scope of the application of the EU visa law, it is worth emphasizing that the consolidation attempts undertaken in the Amsterdam period were doomed to failure due to two different legal and procedural regimes applied, which resulted in the variety of legal instruments operating on the level of the Union. The turning point was the Lisbon reform, which unified the visa requirements practiced by Member States. The adoption of common rules specifying the types of Schengen visas and the procedure for examining applications for shortstay entry permissions has become an important element of the harmonization process. By introducing a single decision-making procedure for all visa matters, the Treaty of Lisbon enabled partial consolidation of the visa acquis, culminating in the adoption of a Common Visa Code in the form of a regulation, which undoubtedly contributed to increased level of legal security in this field.

Currently, the legal basis for the common visa policy is Art. 77 section 2 (a) of the Treaty on the Functioning of the European Union (TFEU), regulating the principles of integrated management of external borders, including the crossing of external and internal borders and conditions for the free movement of third-country nationals within a short period of time on Union territory. However, the basic act regulating the granting of entry permits at EU level remains the Community Visa Code, establishing the legal definition of a Schengen visa and the conditions and procedures

68 Federica Infantino, Schengen Visa Implementation..., op.cit., 45; Elena Jileva, Visa and free movement of labour...op.cit, Boratynski, J., L. Chajewski, P. Hermelinski, A. Szymborska and B. Tokarz, Visa Policies of European Union Member States. Monitoring Report, The Stefan Batory Foundation, Warsaw, 2006.

69 Annalisa Meloni, Visa Code Regulation (EC)..., op.cit., 123.

70 Federica Infantino, Schengen Visa Implementation..., op.cit. 
for issuing it. Notwithstanding the simplification brought about by the regulation, visa issuing remains a complex matter as the Code continues to interlock with a number of other legal instruments ${ }^{71}$. The incomplete nature of the consolidation results from the still existing dispersion of visa matters, which is reflected in the separate provisions that still remain in force, including negative and positive visa lists, uniform visa format and VIS. One may also conclude, that the current legislative visa toolbox is composed of a mix of hard law (like the Visa Code) and soft law (i.e.the Handbook for the processing of visa applications ${ }^{72}$. Thus, currently binding acquis in the field of visas has a complex nature and still remains heterogeneous, which is the result of its dualistic development, running parallel to the Schengen cooperation and actions undertaken by the Community and then the EU.

\section{REFERENCES}

Ananicz Szymon, Partnerstwo Wschodnie, Infos, Biuro Analiz Sejmowych, nr 17, (64) 24.09.2009, In: www.orka.gov.pl [last access: 28.01.2019].

Boratynski, J., Chajewski, L., Hermelinski P, Szymborska A., and Tokarz B., Visa

Policies of European Union Member States. Monitoring Report, The Stefan

Batory Foundation, Warsaw, 2006.

Case C-503/03 Commission v Spain

Cesarz Maciej, Dialog wizowy UE z Turcją w świetle porozumienia o readmisji z I 6 grudnia 2013 roku, In: Integracja europejska. Główne obszary badawcze, eds. K.A. Wojtaszczyk, J. Tymanowski, P. Stawarz, Warszawa, 2015.

Convention implementing the Schengen Agreement of 14 June 1985 between the Governments of the States of the Benelux Economic Union, the Federal Republic of Germany and the French Republic on the gradual abolition of checks at their common borders, OJ L 239, 22.9.2000

Council Regulation (EC) No 1683/95 of 29 May 1995 Laying down a Uniform Format for Visas 1995.

Council Regulation (EC) No 539/2001 of 15 March 2001 listing the third countries whose nationals must be in possession of visas when crossing the ex-

71 A.Meloni, Visa Code Regulation (EC)..., op.cit., p.122.

72 F.Infantino, Schengen Visa Implementation..., op.cit., p.55. 
ternal borders and those whose nationals are exempt from that requirement OJ L 81, 21.3.2001

European Commission (2004) European neighbourhood policy. Strategy paper, Bruxelles: European Commission, (COM(2004)373 final)

European Commission, Evaluation of the implementation of the European Community's visa facilitation agreements with third countries, Commission Staff Working Document SEC (2009)1041final, Bruxelles: European Commission.

Finotelli Claudia, Sciortino Giuseppe, Through the Gates of the Fortress: European Visa Policies and the Limits of Immigration Control, Perspectives on European Politics and Society, 2013.

Handbook for the processing of visa applications and the modification of issued visas. Commission Decision, 19 March 2010, C (2010) 1620 final.

ICMPD, How harmonised can visa policy be? The new EC proposals on Schengen visa rules, Policy Brief, November 2014.

Infantino Federica, Schengen Visa Implementation and Transnational Policymaking. Bordering Europe, PalgraveMacmillan, 2019.

Jileva Elena, Visa and free movement of labour: The uneven imposition of the EU acquis on the accession states, Journal of Ethnic and Migration Studies, 2002, 28(4).

Joppke Christian, Asylum and State Sovereignty: A Comparison of the United States, Germany, and Britain, in: Ch. Joppke (Eds.), Challenge to the Nation-State: Immigration in Western Europe and the United States, Oxford, 1998.

Karamanidou Lena, Kasparek Bernd, Global Migration: Consequences and Responses, Respond Working Papers, Paper 2018/14, July 2018.

Lavenex Sandra, Migration and the EU's new eastern border: Between realism and liberalism, Journal of European Public Policy, 8(1).

Meloni Annalisa, Visa Code Regulation (EC) No 810/2009, In: EU Immigration and Asylum Law - A Commentary, eds. K. Hailbronner, D. Thym, BadenBaden: Nomos, 2016.

Meloni Annalisa, Visa Policy within the European Union Structure, Berlin-Heidelberg, 2006.

Morawska Ewa, Gappy immigration control, resourceful migrants and pendel communities, In: Controlling a new migration world, eds. V. Guiraudon and C. Joppke, 2001.

Moreno-Lax Violeta, Accessing Asylum in Europe.Extraterritorial Border Controls and Refugee Rights under EU Law, Oxford, 2017.

Peers Steve, EU Justice and Home Affairs Law: Volume I: EU Immigration and Asylum Law, Oxford, 2016. 
Regulation (EC) No 767/2008 of the European Parliament and of the Council of 9 July 2008 Concerning the Visa Information System (VIS) and the Exchange of Data Between Member States on Short-Stay Visas.

Regulation (EC) No 810/2009 of the European Parliament and of the Council of 13 July 2009 Establishing a Community Code on Visas (Visa Code) 2009.

Revision of the Common Visa Code, in: www.europarl.europa.eu/legislative-train/ theme-towards-a-new-policy-on-migration/file-revision-of-the-common-visa-code [last access: 28.01.2019].

Revision of the Visa Code (Regulation 810/2009) and Visa Information System (Regulation 767/2008), in: www.europarl.europa.eu/RegData/etudes/ BRIE/2018/615646/EPRS_BRI\%282018\%29615646_EN.pdf [last access: 28.01.2019].

Ruszkowski Janusz, Europeizacja ad extra w zarządzaniu zewnętrznym (external governance) Unii Europejskiej, In: Rocznik Integracji Europejskiej, nr 4, 2010, http://wnpid.amu.edu.pl/images/stories/rie/4-2010/007-028.pdf (access 28.01.2019).

Scott W. James, The EU and Wider Europe: Toward an Alternative Geopolitics of Regional Cooperation?, In: Geopolitics, 2005, vol. 10.

Szachoń-Pszenny Anna, Acquis Schengen a granice wewnętrzne i zewnętrzne w Unii Europejskiej, Poznań, 2011.

Szachoń-Pszenny Anna, Wymiar prawny i terytorialny strefy Schengen, In: System Schengen a imigracja z perspektywy Polski i Niemiec, Ed. M. Trojanowska-Strzęboszewska, Warszawa, 2014.

Treaty on European Union, Consolidated version, OJ C 326, 26.10.2012.

UNHCR. (2011) Asylum Levels and Trends in Industrialized Countries 2010, https://www.unhcr.org/4d8c5b109.pdf

Zaiotti Ruben, Cultures of Border Control: Schengen and the Evolution of European Frontiers, Chicago, 2011. 
